\title{
Production Coefficient Analysis of Indian Manufacturing Industry
}

\author{
${ }^{1}$ Rajni Pathania, ${ }^{2}$ Saleem Anwar \\ ${ }^{1}$ Research Scholar Department of Business Economics Faculty of Commerce The M.S. University of Baroda \\ ,Vadodara Gujarat India \\ ${ }^{2}$ Management Student Lovely Professional University Punjab
}

\begin{abstract}
This paper attempts to make a production coefficient analysis of the 2 digit manufacturing Industries in India for the period 1998-99 to 2007-08. These relates to(i)Average and Incremental output-capital ratio(ii) Average and Incremental output-Labor ratio(iii)Comparison between the growth of total remuneration and Labor Productivity(iv)combined input efficiency and Annual Average growth rate of output and input variables(v)Return to Scale of Manufacturing Industries. This study shows that these manufacturing 2 digit industries are more capital intensive and experiencing increasing return to scale.
\end{abstract}

Keywords: Coefficient, Efficiency, Productivity, Return to Scale, Capital Intensive

\section{Introduction}

Manufacturing industries are the major wealth producing sectors of an economy. Manufacturing industry came into being with the occurrence of technological and socio-economic transformations in the Western countries in the 18th-19th century. This was widely known as industrial revolution. It began in Britain and replaced the labor intensive textile production with mechanization and use of fuels.

The manufacturing industry accounts for an important share of the industrial sector in developing and developed countries. These industries use a variety of technologies and methods broadly known as manufacturing process management. Manufacturing industries are generally categorized into engineering industries, construction industries, electronics industries, chemical industries, energy industries, textile industries, food and beverage industries, metalworking industries, plastic industries, transport and telecommunication industries. Manufacturing industries are important for an economy as they employ a large share of the labor force and produce materials required by sectors of strategic importance such as national infrastructure and defense. However, not all manufacturing industries are beneficial to the nation as some of them generate negative externalities with huge social costs. The cost of letting such industries flourish may even exceed the benefits generated by them. Owing to the emerging technologies worldwide, the world manufacturing industry has geared up and has incorporated several new technologies within its purview. Economists consider the World manufacturing industry as a sector which generates a lot of wealth, Generating employment, introducing latest techniques, real earnings from shipments etc., have put the world manufacturing industry in a favorable position.

The Indian economy is firmly on the path of steady growth. Even during the last decade when other countries were in the grip of a massive slowdown, India continued to enjoy a comfortable economic position. This recent spurt in growth is propelled by radical reforms such as the removal of restrictions on foreign investment and industrial de-licensing.

The liberalization of the economy has opened new windows of opportunity for manufacturing sector. Increasingly the success of manufacturing industries is dependent on innovations, research and development. It is critical not only to remain competitive but also, significant advantages can be gained by developing and commercializing new technologies.

With a size of US \$22 billion, the engineering sector exports stood at US \$ 6.6 billion in 2001-02 and imports at US \$ 4.9 billion the same year. Indian engineering manufacturing sector employs over 4 million skilled and semi-skilled workers. The engineering manufacturing sector comprises of heavy engineering $(70 \%)$ and light engineering (30\%). The manufacturing sector grew by $8.9 \%$ in 2004-05, comfortably outperforming the sector's long-term average growth rate of $7 \%$. The sector has remained one of the engines of economic growth since the start of 2005-06.

\section{I.I Review of literature}

A lot of studies have been done on the different aspects of manufacturing Industry at national and international level. A few studies have been taken for review:

Page (1984), conducted study to examine the relationship between relative technical efficiency and firm size in four Indian manufacturing industries i.e. shoes, printing, soap and machine tools for the financial year 1979-80. 
A frontier translog production function is used to derive measure of technical efficiency. This study found that there is considerable variation in the firm specific indices of technical efficiency within each industry and firm size is found to be positively associated with relative production efficiency in only one of the four industries. The study highlight that average experience of the labour force within the enterprises, experience of entrepreneurs, age of establishment of plant and equipment and level of capacity utilization were identified as significant source of variation in technical efficiency for one or more of the industries.

Mahadevan (2002), examined the total factor productivity growth of twenty-eight Malaysian manufacturing industries from 1981 to 1996. TFP (Total Factor Productivity) growth was measured from two different models of the frontier approach: stochastic frontier model and DEA (Data Envelopment Analysis) model. The stochastic frontier model shown that output growth had been mainly input-driven rather than productivity driven, and that TFP growth had been consistently negative over time. On the other hand, the DEA model had shown consistently positive TFP growth rates. Due to the use of different methods and models, TFP growth rates differ but both models shown that TFP growth was low and declined over time.

Hossain and Karunaratne (2004), examined the effects of the trade liberalisation on the technical efficiency in Bangladesh manufacturing Industry for the decade 1978-94. The estimates obtained from the stochastic frontier inefficiency model. The focus of the study was on panel data for 25 three digit level industries. The study had observed that the technical efficiency of the manufacturing industries had increased over time. The study also found that there was no neutral technical change occurred in the production technology of the Bangladesh manufacturing industries. This study suggested that improvement in technical efficiency of Bangladesh manufacturing sector may be attributed to the competitive push to domestic industries.

Parameswaran (2004), discussed the total factor productivity of the capital goods producing industries. This study examines two components of the total factor productivity growth; one is technical change and second is technical efficiency change. The technical efficiency and technical change are estimated using a stochastic frontier production function. The main result of this study shows that all the industries studied experienced a significant improvement in the rate of technological progress during the post reform period. The result shows that the level of technical efficiency is lower during the post reform period in Indian manufacturing industries.

From the literature review, it can be seen that most of these studies focus on the performance of manufacturing Industry. Study on combined input efficiency of manufacturing industries in India is a field where very little work has been done. Moreover, a lot of studies have been done on the performance of the Indian economy in the post and pre reform period. Most of these studies focus on the comparative analysis of these Industries. Our research study is somewhat unique in the sense that so far, no study has been covered during the period 1998-99 to 2007-08. There is enough scope of research in this area.

\section{I.II Objectives of study}

The specific objectives of this study are:

1. To analyze the average incremental output- capital ratio of 2 digit manufacturing Industries.

2. To analyze the average incremental output-labor ratio of 2 digit manufacturing Industries

3. To analyze the comparison between the growth of total remuneration and labor productivity.

4. To examine the combined input efficiency of 2 digit manufacturing industries.

5. To examine the return to scale of 2 digit manufacturing industries.

\section{I.III Hypothesis of the study}

We have proposed the following hypothesis for this study:

1. $\mathrm{HO}_{1}$ : There is significant difference between average incremental output- capital ratio and average incremental output -labour ratio.

2. $\mathrm{HO}_{2}$ : There is significant growth of combined input efficiency of 2 digit manufacturing Industries.

\section{II.I Data source}

\section{Research methodology}

The study mainly relies upon the Annual Survey of Industries (ASI) data, published by Central Statistical Organization (CSO). The study intends to examine the above-mentioned objectives at 2-digit level of Industry classification. The period of study is from 1998 to 2007-08. The study covers manufacturing industries at all India level. Till the year 1997-98 the ASI data is available in two-digit form. The data from 1998-99 onwards has been collected from ASI- Factory level summary sectors, which is available in three-digit form. These threedigit data have been transformed into two-digit with the help of appropriate concordance.

\section{II.II Research Technique}

We apply here Cobb Douglas production function to estimate elasticity of inputs and return to scale: 


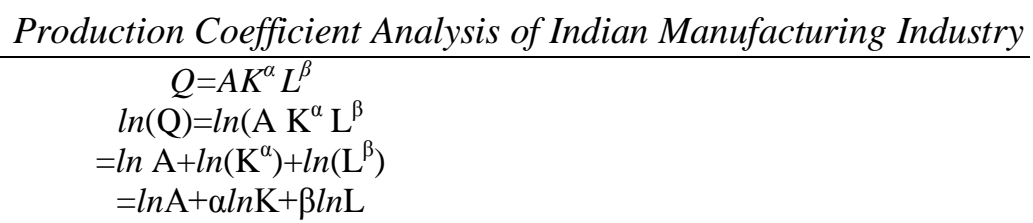

Notice that the last line above has simply transformed the original Cobb-Douglas function to a linear form in logarithms. Hence, the transformed equation is a log-linear version of the original equation. Note that in the loglinear form, the exponent appears as a parameter $(\ln A$ is the intercept, and $\alpha$ and $\beta$ are the slopes, in this $\log$-linear equation). Value-added (Q), number of workers $(\mathrm{L})$ and fixed investment $(K)$ for various years in the Indian Manufacturing industry

The second method used in this study is as:

$\mathrm{AOKR}=\mathrm{Qt} / \mathrm{Kt}$,

$\mathrm{IOKR}=\mathrm{Q} / \mathrm{K}=\mathrm{Q}_{\mathrm{t}}-\mathrm{Q}_{\mathrm{t}-1} / \operatorname{In}_{\mathrm{t}}\left(\right.$ where $\left.I n_{\mathrm{t}}=\mathrm{FC}_{\mathrm{t}}-\mathrm{FC}_{\mathrm{t}-1}\right)$

Where AOKR is Average Output Capital Ratio, IO is Incremental Output, IK is Incremental Capital and IOKR is Incremental Output Capital Ratio.

$\mathrm{AOLR}=\mathrm{Qt} / \mathrm{Lt}, \mathrm{IOLR}=\mathrm{Q} / \mathrm{L}=\mathrm{Q}_{\mathrm{t}}-\mathrm{Q}_{\mathrm{t}-1} / \mathrm{L}_{\mathrm{t}}-\mathrm{L}_{\mathrm{t}-1}$

Where AOKR is Average Output Labor Ratio, IL is Incremental Labor and IOLR is Incremental Output Labor Ratio,

\section{Analysis of production coefficient \\ Table 1}

Average and Incremental Output/ Capital Ratios in the Manufacturing Industries

\begin{tabular}{|c|c|c|c|c|}
\hline Year & $\begin{array}{c}\text { AOKR (Rs. per } \\
\text { unit of K- years) }\end{array}$ & IO(Rs.000s) & IK(Rs. 000s) & $\begin{array}{c}\text { IOKR (Rs. Of VA } \\
\text { per unit of K- } \\
\text { years) }\end{array}$ \\
\hline $1998-99$ & 0.4 & - & - & - \\
\hline $1999-00$ & 0.4 & 951337 & 1071328 & 0.9 \\
\hline $2000-01$ & 0.4 & -1135301 & -226051 & 5.0 \\
\hline $2001-02$ & 0.3 & 68071 & 3235591 & 0.0 \\
\hline $2002-03$ & 0.4 & 2803792 & 1279925 & 2.2 \\
\hline $2003-04$ & 0.4 & 3059272 & 2857202 & 1.1 \\
\hline $2004-05$ & 0.5 & 5697410 & 3973785 & 0.6 \\
\hline $2005-06$ & 0.5 & 5195733 & 9387103 & 0.8 \\
\hline $2006-07$ & 0.6 & 8386107 & 10819111 & 0.7 \\
\hline $2007-08$ & 0.6 & 8586742 & 13000070 & \\
\hline
\end{tabular}

Source: Researcher's own calculation based on ASI data 1998-2007

Table 1 indicates the average and incremental output/ capital ratio in manufacturing industry, between years 1998 to 2008. For the period 1998-99 to 2000-01, one rupee of fixed capital on the average was associated with Rs. 0.4 of the value added. But whilst the 2001-02 points lie far below this line denoting a server deterioration in capital productivity, but the observation for the period 2004-05 to 2007-08 is above this line indicating an improvement. The evidence on the incremental output capital ratio of manufacturing industry indicates somewhat satisfactory performance after the year 2000-01.

Table 2

Average and Incremental Output/ Labor Ratios in the Manufacturing Industries

\begin{tabular}{|c|c|c|c|c|}
\hline Year & $\begin{array}{c}\text { AOKR (Rs. per } \\
\text { man - years) }\end{array}$ & IO(Rs.000s) & IL(No's) & $\begin{array}{c}\text { IOKR (Rs. Of VA } \\
\text { per man- years) }\end{array}$ \\
\hline $1998-99$ & 2.3 & & & -11.4 \\
\hline $1999-00$ & 2.5 & 951337 & -83805 & 7.8 \\
\hline $2000-01$ & 2.3 & -1135301 & -145421 & -0.4 \\
\hline $2001-02$ & 2.4 & 68071 & -177390 & 13.8 \\
\hline $2002-03$ & 2.8 & 2803792 & 203645 & -41.0 \\
\hline $2003-04$ & 3.3 & 3059272 & -74585 & 11.1 \\
\hline $2004-05$ & 3.9 & 5697410 & 512390 & 9.7 \\
\hline $2005-06$ & 4.4 & 5195733 & 536799 & 11.3 \\
\hline $2006-07$ & 5.0 & 8386107 & 744439 & 27.0 \\
\hline $2007-08$ & 5.9 & 8586742 & 317574 & \\
\hline
\end{tabular}

Source: Researcher's own calculation based on ASI data 1998-2007 
Production Coefficient Analysis of Indian Manufacturing Industry

From table 2, it is noticed that labor productivity or the average output/ employment ratio had, except for the years 1998-99, 2001-02 and 2003-04, shown wide variation; it was high in 2007-08, negative in 1999-00, 200102 and 2003-04. After 2003-04 it became positive.

Table 3

Comparison between the Indexes of Growth of Remuneration/ wages and Labor Productivity

\begin{tabular}{|c|c|c|}
\hline Year & $\begin{array}{c}\text { Remuneration/Wage- Bill } \\
\text { Index }\end{array}$ & Labour productivity Index \\
\hline $1998-99$ & 100.0 & 100.0 \\
\hline $1999-00$ & 106.0 & 98.7 \\
\hline $2000-01$ & 111.5 & 96.4 \\
\hline $2001-02$ & 110.5 & 93.6 \\
\hline $2002-03$ & 119.6 & 96.8 \\
\hline $2003-04$ & 122.8 & 95.6 \\
\hline $2004-05$ & 135.5 & 103.7 \\
\hline $2005-06$ & 151.7 & 112.1 \\
\hline $2006-07$ & 178.4 & 123.8 \\
\hline $2007-08$ & 205.5 & 128.8 \\
\hline
\end{tabular}

Source: Researcher's own calculation based on ASI data 1998-2007

Table 3 reflects that the labor productivity index was 100 in the starting year 1998-99, thereafter, it declined almost consistently till the year 2003-04. In other words, during the period 1998 to 2003-04 there were full fluctuations in labor productivity. A sharp uptrend in labor productivity was noticed during the period 2004 to 2007 , on the other hand the trend in the wage bills and total remuneration have been noticed increased in overall period of the study.

Table 4

Indexes of Combined Input and Efficiency of the 2- Digit Manufacturing Industry

\begin{tabular}{|c|c|c|c|c|c|}
\hline Year & $\begin{array}{c}\text { Index of Net } \\
\text { Value Added }\end{array}$ & $\begin{array}{c}\text { Index of } \\
\text { Labor }\end{array}$ & $\begin{array}{c}\text { Index of } \\
\text { Capital }\end{array}$ & $\begin{array}{c}\text { Index of } \\
\text { Combined } \\
\text { Inputs }\end{array}$ & $\begin{array}{c}\text { Index of } \\
\text { Efficiency }\end{array}$ \\
\hline $1998-99$ & 100.0 & 100.0 & 100.0 & 100.0 & 100.0 \\
\hline $1999-00$ & 106.5 & 98.7 & 102.7 & 99.8 & 106.8 \\
\hline $2000-01$ & 98.7 & 96.4 & 102.2 & 98.0 & 100.8 \\
\hline $2001-02$ & 99.2 & 93.6 & 110.4 & 98.2 & 101.1 \\
\hline $2002-03$ & 118.5 & 96.8 & 113.7 & 101.4 & 116.9 \\
\hline $2003-04$ & 139.5 & 95.6 & 121.0 & 102.5 & 136.1 \\
\hline $2004-05$ & 178.7 & 103.7 & 131.2 & 111.1 & 160.8 \\
\hline $2005-06$ & 214.4 & 112.1 & 155.2 & 123.7 & 173.3 \\
\hline $2006-07$ & 272.0 & 123.8 & 182.8 & 139.8 & 194.7 \\
\hline $2007-08$ & 331.1 & 128.8 & 216.1 & 152.4 & 217.3 \\
\hline
\end{tabular}

Source: Researcher's own calculation based on ASI data 1998-2007

Table 5

Growth Rate of Efficiency, Combined Input, Net Value Assed, Capital and Labor

\begin{tabular}{|c|c|c|c|c|c|}
\hline Year & Efficiency & $\begin{array}{c}\text { Combined } \\
\text { Input }\end{array}$ & Capital & Labor & $\begin{array}{c}\text { Net Value } \\
\text { Added }\end{array}$ \\
\hline $1999-00$ & 6.8 & -0.2 & 2.7 & -1.3 & 6.5 \\
\hline $2000-01$ & -5.6 & -1.8 & -0.6 & -2.3 & -7.3 \\
\hline $2001-02$ & 0.3 & 0.2 & 8.1 & -2.9 & 0.5 \\
\hline $2002-03$ & 15.6 & 3.2 & 3.0 & 3.4 & 19.4 \\
\hline $2003-04$ & 16.5 & 1.1 & 6.4 & -1.2 & 28.1 \\
\hline $2004-05$ & 18.1 & 8.6 & 8.4 & 8.4 & 20.0 \\
\hline $2005-06$ & 7.7 & 12.6 & 18.3 & 10.4 & 26.9 \\
\hline $2006-07$ & 12.4 & 16.0 & 17.8 & 4.0 & 21.7 \\
\hline $2007-08$ & 11.6 & 12.6 & 18.2 & $2.6 \%$ & $13.3 \%$ \\
\hline $\begin{array}{c}\text { Annual Average } \\
\text { Rate of Growth: }\end{array}$ & $8.3 \%$ & $5.2 \%$ & $8.2 \%$ & & \\
\hline
\end{tabular}

Source: Researcher's own calculation based on ASI data 1998-2007 
Table 4 and table 5 indicate that the annual growth rate of the composite index of labor and capital productivity in the 2 -digit manufacturing industry during 1998-99 to 2007-08, was 8.3. These tables also demonstrate that index of efficiency fell marginally to 100.79 in the period 2000-01. Thereafter, efficiency climbed steadily till 2007-08. The same fluctuation was seen in year to year growth rate. The annual average rate of growth of the combined input was observed $5.2 \%$ whereas the annual average rate of growth of capital, labor and value added was $8.2 \%, 2.6 \%$ and $13.3 \%$ respectively.

\section{III.I Production function analysis of 2- digit manufacturing industry in India}

Production function in a manufacturing Industry is a value adding process and it expresses the technical relationship that exists between factor of inputs and output. It is typical in economics to consider output as a function of two prime factor of production namely labor and capital. In this study, output has been defined as the net value added by manufacturing Industry, capital as fixed Investment and Labor units in terms of Number of workers in the Industry. The Cob Douglas form of production function has been used for this time series data of the manufacturing industries to estimate the productivity of the factors for the year 1998-99 to 2007-08. This form of production function not only satisfies the basic economics laws but also easy in its computation and interpretation of the estimated parameters.

The estimated Equation is:

$$
\begin{gathered}
\ln \mathrm{Q}=\ln (-16.64)+\ln (1.48) \mathrm{K}+\ln (0.463) \mathrm{L} \\
\mathrm{R}^{2}=0.97 \quad(\mathrm{~F}-\text { Value: } 114.05) \quad(\mathrm{t}-\text { value: } 4.455) \quad(\mathrm{t}-\text { value: } .591)
\end{gathered}
$$

The estimated results for the factory sector of India make it clear that the elasticity of capital with respect to value added is about 1.48 and that of labor is 0.463 . The estimated result make it clear that the Indian manufacturing Industry(Factory sector) is more capital intensive and are experiencing increasing return to scale. The significant negative coefficient of time indicates a downward trend in total factor productivity. The F- test for the model also indicates it is highly significant, $\mathrm{F}=114.05$ at sig $\mathrm{F}=.0000$. this result also indicates that the $\mathrm{t}$ - test for the significance of individual independent variables indicates that at the significance level of 0.95(confidence level of $95 \%$ ), only capital is statistically significant in the model, other variable i.e labor are individually not significant at 95 percent confidence limit. The explanatory power $\left(R^{2}\right)$ of the model is capable of explaining nearly 97 percent of the changes in the value added which are due to the changes in the labor and capital.

\section{IV.I Conclusion}

\section{Conclusion, Limitations and Suggestions}

The objective of this study was to investigate and analyze the incremental output - capital ratio of 2 digit manufacturing Industries and to analyze the average incremental output-labor ratio of 2 digit manufacturing Industries. The findings of this empirical study show that all the formulated hypotheses were in the same direction as was hypothesized in the study. From the above results and analysis we could draw the conclusion as below:

- Incremental output- capital ratio has increased more than the average output- capital ratio.

- Average Output - Labor Ratio has increased during the entire study period.

- Estimates of Total factor Productivity reveals a significant decline in Total Factor Productivity in 2 - digit manufacturing Industries.

- According to the result of Cobb Douglas production function, Increasing Return to Scale is in operation in this industry.

\section{IV.II Limitation of the study:}

The limited database, short time period and selected variables are some of the major limitations of this study. However in future research scholars or students can work on more variables which will provide better experience to the students for their bright career.

\section{IV.III Suggestions}

It is obvious from the study that embarking upon changing macro policies will not be enough to improve efficiency and total factor productivity in this industry. There is need to restructure the Indian 2-digit manufacturing Industries. Emphasis should be given to technological progress, skill levels of the workers, foreign investment, and level of competition. Lack of availability of inputs, Inadequate infrastructure, inappropriate policy support from various government organisation are some of the challenges in front of these manufacturing industries, so alternative policies must be formulated by the policymakers for these Industries. 


\section{References}

[1] R. Mahadevan, Is There a Real TFP Growth Measure for Malaysia's Manufacturing Industries?, ASEAN Economic Bulletin,19(2), August-2002,178-190.

[2] M. Page, Firm size and technical efficiency: Application of production frontiers to Indian survey data, Journal of Development Economics, 16(1-2),1984, 129-152.

[3] M. Parameswaran, Economic reforms, Technical change and Efficiency change: firm level evidence from capital goods Industries in India, Indian Economic Review, 39(1), 2004, 239-260.

[4] S. Hussain, Performance of Small Scale Industries in India and the Challenges Ahead, Indian Journal of Industrial Relations, 39(3), 2004, 391-401 